\title{
BIOTRANSFORMATION OF FLAVONOLS TO FLAVONOLS-3-O- GLUCOSIDE IN CELL CULTURES OF ASTRAGALUS SIEBERI DC.
}

\author{
A. M. A. Abd El-Mawla and Zedan Z. Ibraheim \\ Department of Pharmacognosy, Faculty of Pharmacy, Assiut University, Assiut, Egypt
}

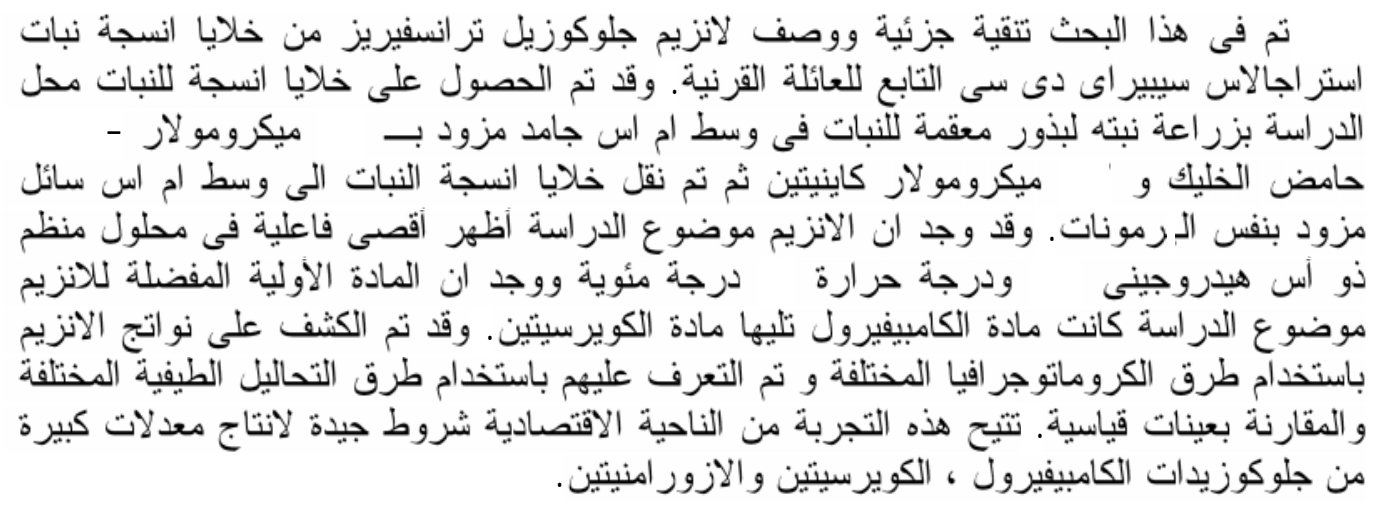

\begin{abstract}
One distinct glucosyltransferase (GT) has been partially purified and characterized from cell cultures of Astragalus sieberi DC.; Family Leguminosae. Callus cultures were established from shoots of sterile germinated seeds maintained on solid MS medium supplemented with 4.5 $\mu M$ 1-naphthylacetic acid (NAA) and $2.3 \mu M$ kinetin (KIN). The cell suspension cultures were obtained by transport of callus cultures to liquid MS medium with the same hormone supplementation. The GT was found to exhibit maximum activity at $\mathrm{pH} 7.5$ and an incubation temperature of $35^{\circ}$. The preferred substrate of GT was found to be kaempferol, the second best substrate was quercetin. The isolated enzymatic products were detected by TLC and HPLC and identified by spectral analysis and comparison with authentic compounds.

This experiment from economic point of view provides the best conditions for large scale production of glucosides of kaempferol, quercetin and isorahmnetin.
\end{abstract}

\section{INTRODUCTION}

Three flavonoid glycosides, kaempferol-3O- $\beta$-D-glucopyranoside (astragalin), kaempferol-3-O-rutinoside and kaempferol-3-O-(2galactose-rhamnosyl-robinobioside) (mauritianin), as well as aglycones apigenin, kaempferol and quercetin, were isolated and identified from the cell suspension cultures of Astragalus sieberi DC. ${ }^{1}$ These compounds exhibited hepatoprotective and free radical scavenging activities. ${ }^{2-5}$

Researches on the transfer of glucose to distinct flavonoid acceptor molecules are numerous, ${ }^{6-12}$ yet only poor information on the enzymatic synthesis of flavonol-3-O-glucoside was found. ${ }^{6,7}$ The commercial production of a pharmaceutical substance by plant cell culture has already been realized on an industrial scale in the case of shikonin, a naphthaquinone pigment with antibacterial, antiphlogistic and wound healing properties that is obtained from cell cultures of Lithospermum erythrorhizon, ${ }^{13}$ for the same reason, our study deals with partial purification and characterization of the glucosyltransferase (GT), in addition, using this enzyme in large scale production of flavonols glucoside specially those compounds have reported biological activities as mentioned above.

\section{MATERIALS AND METHODS}

\section{Chemicals}

Kaempferol, quercetin, isorhamnetin, apigenin, luteolin, fisetin, galangin, myricetin, gossypetin, Kaempferol-3-O-glucoside, quercetin-3-O-glucoside and isorahmnetin-3-O- 
glucoside were obtained from Institute for Pharmaceutical Biology, University of Bonn, Germany.

UDP-D-glucose from Sigma, München. Dithiothreitol (DTT) from Applichem, Darmstadt. Polyclar AT from Serva, Heidelberg. Potassium dihydrogen phosphate, seasand and ammonium sulphate from Merck, Darmstadt.

\section{Equipments}

UV spectra were determined in Unicam SP-1750 ultraviolet spectrometer. EI-MS spectra were carried out on Hitachi M-80 and on MAT 311A, 70 ev. spectrometer. ${ }^{1} \mathrm{H}-\mathrm{NMR}$ $(500 \mathrm{MHz})$ spectra were determined in DMSO$\mathrm{d}_{6}$ using TMS as internal standard.

\section{Cell cultures}

Calli cultures of Astragalus sieberi DC. were established from the shoots of sterile germinated seeds maintained on solid MS (Murashige and Skoog), ${ }^{14}$ containing 0.8\% agar and $20 \mathrm{~g} / \mathrm{l}$ sucrose and supplemented with 4.5 $\mu \mathrm{M}$ indole-3-acetic acid (IAA) and $2.3 \mu \mathrm{M}$ kinetin (KIN). Calli cultures were initiated and maintained on solid MS medium at $25 \pm 1^{\circ}$ in the light. Cultures were sub-cultured at the end of exponential growth phase, at 4-week intervals. ${ }^{1}$

Cell-suspension cultures of Astragalus sieberi DC. were established as described previously $^{1}$ on liquid MS medium supplemented with $4.5 \mu \mathrm{M}$ 1-naphthylacetic acid (NAA) and $2.3 \mu \mathrm{M}$ kinetin (KIN) from calli grown on solid MS medium with the same hormone supplementation.

\section{Buffer solution}

The following buffer solution was used: $0.1 \mathrm{M}$ potassium phosphate buffer $(\mathrm{pH} 7.5)$, containing 1.0 mM DTT.

\section{Enzyme extraction}

Cell-free extracts were prepared as described in literatures. ${ }^{15,16}$ Cells (4 g) were mixed with $0.4 \mathrm{~g}$ polyclar AT and a spatula of seasand and homogenised for $15 \mathrm{~min}$ in $2.5 \mathrm{ml}$ $0.1 \mathrm{M}$ potassium phosphate buffer $(\mathrm{pH} 7.5)$ containing $1.0 \mathrm{mM}$ DTT. After centrifugation in a super-speed refrigerated centrifuge at 12000 r.p.m. and $4^{\circ}$ for 20 min the supernatant was passed through a $\mathrm{PD}_{10}$ column (Amersham
Pharmacia Biotech) and the high-molecular weight fraction was eluted with $3.5 \mathrm{ml}$ of the same buffer.

\section{Enzyme assay}

The assay system ${ }^{17}$ contained in $100 \mu \mathrm{l}$ total volume: $65 \mu \mathrm{l} 0.1 \mathrm{M}$ potassium phosphate buffer (pH 7.5), $30 \mu$ l enzyme extract (about 15-25 $\mu \mathrm{g}$ protein), $700 \mathrm{nmol}$ uridine 5diphosphoglucose (UDPGlc) and $50 \mathrm{nmol}$ kaempferol. The reaction was started by addition of UDPGlc. The incubation was carried out for $15 \mathrm{~min}$ at $35^{\circ}$ and was terminated by addition of $40 \mu \mathrm{l}$ chloroformmethanol, $(2: 1, \mathrm{v} / \mathrm{v}$; plus $0.5 \% \mathrm{HCl})$, resulting in a Folch partition. ${ }^{18}$ The flavonoids were concentrated in the upper phase and the reaction mixture was analysed by highperformance liquid chromatography (HPLC) and thin layer chromatography (TLC). ${ }^{1}$

A control experiment was carried out by further incubation as mentioned above, using denatured protein (boiled enzyme extract); 100 $\mu l$ enzyme extract was heated in boiling water bath for $10 \mathrm{~min}$ (heat inactivation) and from which $30 \mu \mathrm{l}$ was added to the incubation assay.

\section{Protein determination}

Protein was determined as described by Bradford. ${ }^{19}$

\section{Ammonium sulphate precipitation}

A cell-free extract $(25 \mathrm{ml})$ obtained from $40 \mathrm{~g}$ of freshly harvested cells was fractionated by addition of ammonium sulphate, reaching $70 \%$ saturation in $10 \%$ steps. $^{20}$

\section{Determination of the $\mathrm{pH}$ and temperature optima}

The assay for the enzyme studied was carried out at different $\mathrm{pH}$ values between 6.0 and 9.0. At the optimum $\mathrm{pH}$ value another series of incubations were performed at different temperatures between 20 and $55^{\circ}$. Two independent experiments were performed and mean values were calculated.

\section{Study of substrate specificity}

At the $\mathrm{pH}$ and temperature optima, enzyme assay was performed using a series of related substrates for the enzyme studied. All substrate concentrations were saturating, i.e. a further increase in substrate concentration did 
not lead to a further increase in product amount.

\section{Analytical methods}

Analysis of the enzymatic product was performed by HPLC and TLC. Fifty $\mu$ of the upper phase were injected into an HPLC apparatus (L-6200 A intelligent pump, L-4000 UV detector, Merck Hitachi, Japan) equipped with a Nucleosile 100-5 $\mathrm{C}_{18}$ column (Macherey-Nagel, Düren, Germany). Eluents were water (A) and methanol (B), both containing $1 \%$ phosphoric acid. The flow rate was $1 \mathrm{ml} / \mathrm{min}$. Flavonoids were eluted with a linear gradient: $20 \%$ B for 4 min, 20 to $70 \%$ B for $22 \mathrm{~min}, 70-100 \% \mathrm{~B}$ for $2 \mathrm{~min}$. Detection was done at a wavelength of $366 \mathrm{~nm}$. The retention time $\left(\mathrm{R}_{\mathrm{t}}\right)$ for the enzymatic product was $10 \mathrm{~min}$ and for its aglycone precursor (kaempferol) was 24 min.

The enzymatic product was isolated by preparative TLC on silica gel $60 \mathrm{~F}_{254}$-coated aluminium sheets (Merck, Darmstadt) using $\mathrm{CHCl}_{3}-\mathrm{CH}_{3} \mathrm{OH}$ (7: 3) as a solvent system, further purification was carried on HPLC. ${ }^{1}$ The $\mathrm{R}_{\mathrm{F}}$ value for the enzymatic product was 0.41 and it was 0.83 for its aglycone kaempferol.

\section{RESULTS AND DISCUSSION}

\section{Results}

Incubation of Kaempferol and UDPGlc with desalted cell-free extract from Astragalus sieberi cell cultures resulted in the formation of kaempferol-3-O- $\beta$-D-glucopyranoside (Fig. 1). The identity of the enzymatic product was shown by co-chromatography (TLC and HPLC) with a sample of authentic compound and by comparing its spectroscopic data (UV, MS, $\left.{ }^{1} \mathrm{H}-\mathrm{NMR}\right)$ with published data. ${ }^{1,21} \mathrm{UV}$ : $\lambda_{\max }\left(\mathrm{CH}_{3} \mathrm{OH}, \mathrm{nm}\right) 266,371 ; \lambda_{\max }\left(\mathrm{CH}_{3} \mathrm{OH}+\right.$ $\left.\mathrm{NaOCH}_{3}, n \mathrm{~nm}\right) 278,416 ; \lambda_{\max }\left(\mathrm{CH}_{3} \mathrm{OH}+\right.$ NaOAc, nm) 276, 393; $\lambda_{\max }\left(\mathrm{CH}_{3} \mathrm{OH}+\right.$ $\left.\mathrm{NaOAc} / \mathrm{H}_{3} \mathrm{BO}_{3}, \mathrm{~nm}\right) 269,373 ; \lambda_{\max }\left(\mathrm{CH}_{3} \mathrm{OH}+\right.$ $\left.\mathrm{AlCl}_{3}, \mathrm{~nm}\right) 272,375 ; \lambda_{\max }\left(\mathrm{CH}_{3} \mathrm{OH}+\mathrm{AlCl}_{3} /\right.$ $\mathrm{HCl}, \mathrm{nm})$ 272, 373. EI-MS $\mathrm{m} / z$ (rel. int.): 286 (16) [ $\mathrm{M}^{+}$agl.], 258 (11), 153 (4), 149 (33), 125 (8), 61 (100), 43 (34). ${ }^{1} \mathrm{H}-\mathrm{NMR}(500 \mathrm{MHz}$, DMSO-d $\left.{ }_{6}\right): \delta 5.50(1 \mathrm{H}, \mathrm{d}, \mathrm{J}=7.1 \mathrm{~Hz}, \mathrm{H}-1 \mathrm{glu})$, $6.21(1 \mathrm{H}, \mathrm{d}, \mathrm{J}=2.1 \mathrm{~Hz}, \mathrm{H}-6), 6.46(1 \mathrm{H}, \mathrm{d}, \mathrm{J}=$
$2.1 \mathrm{~Hz}, \mathrm{H}-8), 7.10(2 \mathrm{H}, \mathrm{dd}, \mathrm{J}=8.4,1.4 \mathrm{~Hz}, \mathrm{H}-$ `3, H-`5), 8.10 (2H, dd, J= 8.4, 1.4 Hz, H-`2, H'6).

No product formation occurred when protein extracts were heat inactivated. Protein extracts were fractionated by stepwise addition of ammonium sulphate (Fig. 2). The protein fraction which precipitated between 50 and $60 \%$ ammonium sulphate saturation contained high glucosyltransferase activity. The enzyme exhibited maximum activity at $\mathrm{pH} 7.5$ and $35^{\circ}$ (Fig. 3).

Studies of the substrate specificity of glucosyltransferase revealed that the preferred substrate was really kaempferol (Table 1). The second best substrate was quercetin and the third one was isorhamnetin.

The other enzymatic products; quercetin3-O-glucoside and isorhamnetin-3-O-glucoside were identified by co-chromatography (TLC and HPLC) with a samples of authentic compounds, in addition comparing their UV and melting points with reported data. ${ }^{2-5,21}$

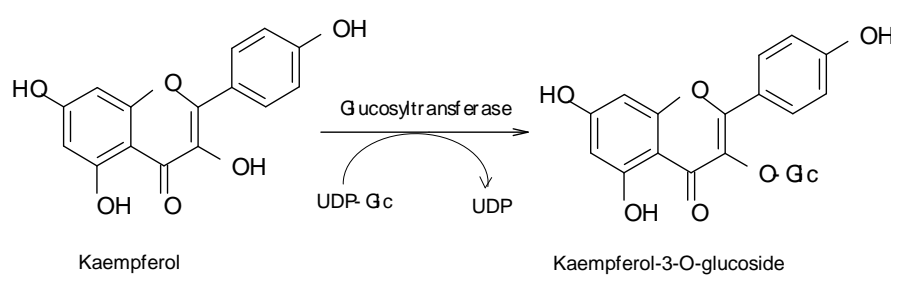

Fig. 1: Reaction catalysed by glucosyltransferase

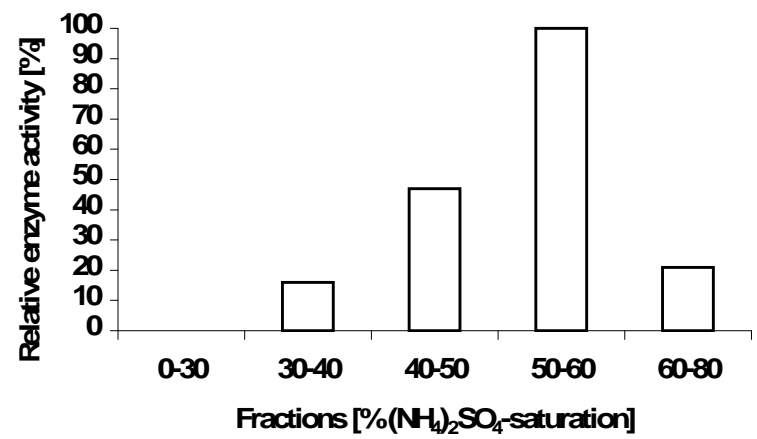

Fig. 2: Distribution of UDP-glucose: flavonol 3-O-glucosyltransferase activity in ammonium sulphate-precipitated protein fractions from Astragalus sieberi cell cultures 

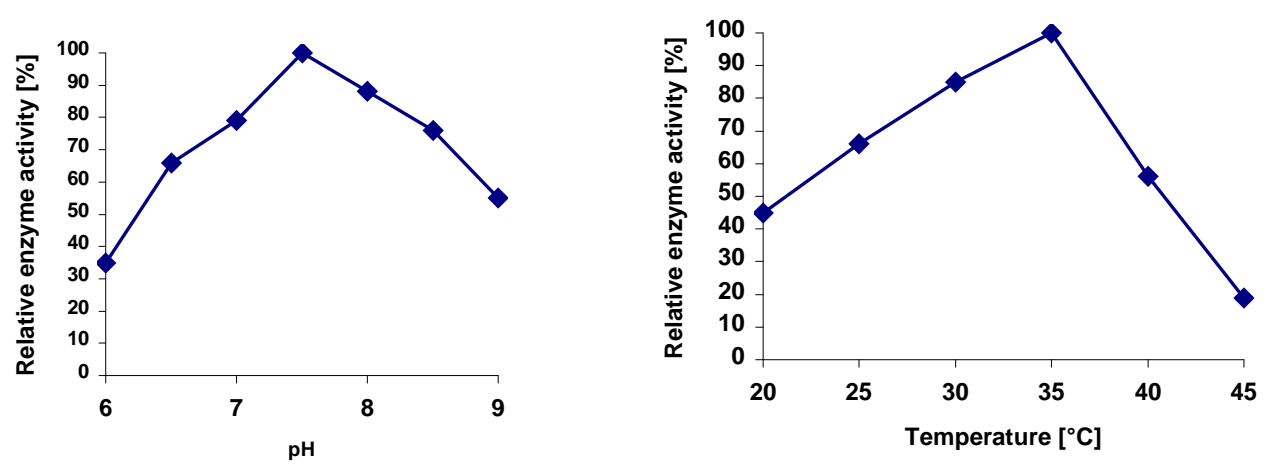

Fig. 3: $\mathrm{pH}$ and temperature optima of UDP-glucose: flavonol 3-O-glucosyltransferase from Astragalus sieberi cell cultures

Table 1: Substrate specificity of UDP-glucose: flavonol 3-O-glucosyltransferase from Astragalus sieberi cell cultures. Cell free extracts were subjected to ammonium sulphate precipitation. The $50-60 \%$ fraction (Fig. 1) was used to study the substrate specificity.

\begin{tabular}{|l|c|}
\hline \multicolumn{1}{|c|}{ Substrate } & $\begin{array}{c}\text { Relative enzyme } \\
\text { activity }(\%)\end{array}$ \\
\hline Kaempferol & 100 \\
Quercetin & 48 \\
Isorhamnetin & 18 \\
Apigenin & 0 \\
Luteolin & 0 \\
Fisetin & 0 \\
Galangin & 0 \\
Myricetin & 0 \\
Gossypetin & 0 \\
\hline
\end{tabular}

\section{Discussion}

In cell suspension cultures of Astragalus sieberi DC., a distinct glucosyltransferase (GT) has been partially purified and characterized. It catalyzes the transfer of the glucosyl moiety of uridine 5-diphosphoglucose (UDPGlc) to the 3-hydroxyl group of flavonol aglycones.

The investigation reported here was closely related to others performed on different systems such as intact plants and cell cultures ${ }^{6-9}$ Moreover, the UDP-glucose: flavonol 3-Oglucosyltransferase has also been isolated from cell suspension cultures of parsley ${ }^{8}$ and from anthers of Tulipa cv. Apeldoorn. ${ }^{17}$ Most properties of the investigated enzyme are in accordance with those reported from the literature: $\mathrm{pH}$ and temperature optima are 7.5 and $35^{\circ}$, respectively. ${ }^{9,12}$ Cations like $\mathrm{Mg}^{2+}$, $\mathrm{NH}_{4}$ and $\mathrm{Ca}^{2+}$ as well as EDTA did not or only poorly affect GT which agree with results reported. ${ }^{7,23,24}$ With regards to its substrate specificity (Table 1), GT from Astragalus sieberi cell cultures predominantly glucosylates flavonols particularly flavonol aglycones like kaempferol, quercetin and isorhamnetin. Activity could not be detected with flavones like apigenin and luteolin. The enzyme acts specifically in the 3-O-position; the 7-Oglucosyltransferase activity previously described for enzyme preparations from parsley cell suspension cultures ${ }^{7,8,11}$ could not be detected.

From the previous work, we came to a conclusion that; the application of protein extract of Astragalus sieberi proved to be successful for the large scale production of glucosides of kaempferol, quercetin and isorahmnetin in the laboratory. In addition, this work presents in the future a good start for carrying out genetic study of glucosyltransferase (GT). Genetic engineering as allowed the production of plants with an altered content of secondary metabolites, gene expression of GT in Astragalus sieberi cell cultures will lead to strong increase of kaempferol-3-O- $\beta$-D-glucopyranoside and carrying out such experiments in the future may prove useful for the production of secondary metabolites of pharmaceutical 
importance, both by intact plants and by plant cell cultures.

Accordingly, we recommend the application of this technique in industry aiming for producing those types of glucosides in large amount enough for market requirements.

\section{Acknowledgement}

We would like to thank Dr. G. Eckhardt and Dr. W. Tomberg (Institute for Organic Chemistry, University of Bonn, Germany) for performing mass and ${ }^{1} \mathrm{H}-\mathrm{NMR}$ spectra, respectively.

\section{REFERENCES}

1- A. M. A. Abd El-Mawla and A. A. Attia, Bull. Pharm. Sci., Assiut University, 25: 79-83 (2002).

2- C. W. Beninger and G. L. Hosfield, J. Agric. Food Chem., 27, 7879-7883 (2003).

3- L. Parejo, F. Viladomat, J. Bastida, G. Schmeda-Hirschmann, J. Burillo and C. Codina, J. Agric. Food Chem., 7, 18901897 (2004).

4- K. M. Janisch, G. Williamson, P. Needs and G. W. Plumb, Free Radic. Res., 8, 877-884 (2004).

5- H. Oh, D. H. Kim, J. H. Cho and Y. C. Kim, J. Ethnopharmacol, 2-3, 421-424 (2004).

6- G. A. Barber, Biochemistry, 1, 463-468 (1962).

7- A.Sutter, R. Ortmann and H. Grisebach, Biochem. Biophys. Acta, 258, 71-87 (1972).

8- A. Sutter and H. Grisebach, Biochem. Biophys. Acta, 309, 289-295 (1973).

9- J. E. Poulten and M. Kauer, Planta, 136, 53-59 (1977).

10- K. F. F: Kho, J. Kamsteeg and J. van Brederode, Z. Pflanzenphysiol., 88, 449464 (1978).
11- J. Köster and W. Barz, Arch. Biochem. Biophys., 212, 98-104 (1981).

12- W. Hösel, Glucosylation and glucosidases. In: The Biochemistry of plants, (E. E. Conn, ed.), vol. 7, Secondary Plant Products, pp. 725-753 (1981), Academic Press, New York, London, Toronto, Sydney, San Francisco.

13- M. Tabata and Y. Fujita, Production of shikonin by plant cell cultures. In P Day, M, Zaitlin, A, ollaender, eds., Biotechnology in Plant Science, Academic Press, Orlando, FL, pp. 207-218 (1985).

14- T. Murashige and F. Skoog, Physiol. Plant., 15, 473 (1962).

15- S. Peters, W. Schmidt and L. Beerhues, Planta, 204, 64-69 (1998).

16- A. M. A. Abd El-Mawla, W. Schmidt and L. Beerhues, Planta, 212, 288-293 (2001).

17- M. Teusch, G. Forkmann and W. Seyfferet, Planta, 168, 586-591 (1986).

18- J. Folch, M. Less and G. H. SaaneStanley, J. Biol. Chem., 226, 496-509 (1957).

19- M. M. Bradford, Analyt. Biochem., 72, 248-254 (1976).

20- W. Barillas and L. Beerhues, Planta, 202, 112-116 (1997).

21- J. Harborne and T. Mabry, "The flavonoids: Advances in Research", $1^{\text {st }}$ Ed., University Press, Cambridge, pp. 9899 (1982).

22- G. Kleinehollenhorst, H. Behrens, G. Pegels, N. Srunk and R. Wiermann, Z. Naturforsch., 37c, 587-599 (1982)

23- R. K. Ibrahim and H. Griesbach, Arch. Biochem. Biophys., 176, $700-708$ (1976).

24- R. K., Ibrahim, Z. Pflanzenphysiol., 85, 253-262 (1977). 